\title{
THE ROLE OF PARENTS IN THE IMPLEMENTATION OF GUIDANCE AND COUNSELING SERVICES TECHNOLOGY DURING THE COVID-19 PANDEMIC
}

\author{
Awalya Awalya ${ }^{1}$, \\ Yudhi Purwa Nugraha ${ }^{2}$, \\ Endang Rifani, \\ Angga Yuda Meilanda ${ }^{4}$, \\ Rudianto Jati Widigdo ${ }^{5 i}$ \\ 1,4,5Universitas Negeri Semarang, \\ Indonesia \\ 2Universitas Islam Jember, \\ Indonesia \\ ${ }^{3}$ Universitas Nahdlatul Ulama Al-Ghazali, \\ Indonesia
}

\begin{abstract}
:
During the COVID-19 pandemic, guidance and counseling teachers are demanded to keep running counseling services using various alternatives of online learning applications. At the same time, parents as the main assistants in the online counseling process should actively encourage their children to have active participation. It is because the majority of parents consider that all the things related to school activities are totally teachers' responsibility. Thus, the present study attempted to find, reveal, and describe the role of parents in the implementation of supporting technology for online counseling services during the COVID-19 pandemic. To do so, the researchers adopted an online survey method and cross-sectional technique to analyze the data of 350 student's parents in Semarang Regency as the respondents of this study. Generally, the findings indicated that parents with high level of understanding tend to provide great support for the online counseling services given to their children.
\end{abstract}

Keywords: the role of parents, online counseling, COVID-19 pandemic

\section{Introduction}

The COVID-19 pandemic has greatly affected educational policies determination. One of which is the online learning policy. Online learning is often held via Google Classroom,

\footnotetext{
i Correspondence: email awalya@mail.unnes.ac.id, yudhi.purwa94@gmail.com, endangrifani.fkip@unugha.id, anggayudam@gmail.com, jatirudianto@students.unnes.ac.id
} 
Zoom, educational television, interactive learning on rumah belajar, ruang guru and other online learning applications. This condition also urges counseling services as one of school instrument which plays a crucial role to implement online services. Putra and Shofaria (2020) argue that the latest educational model, namely Study From Home (SFH) is not supposed to be used as an alternative medium to do face-to-face meeting while guidance and counseling teachers are doing Work From Home (WFH). Instead, online guidance and counseling services should be done meaningfully and given to optimize students' development in achieving their developmental tasks through the utilization of some online platforms available on the internet.

During the COVID-19 pandemic, counselors can empower students from stress, anxiety, and other problems using technology and social media, such as providing consultation videos (Greenhalgh et al., 2020). Surely, this condition forces students to learn from home, while parents must prepare supporting devices for the counseling services, such as smartphone, internet quota, and other supporting facilities for the success of learning process (Gunawan, et al., 2020). Therefore, technology utilization in the online guidance and counseling must be the answer for challenges and issues during the COVID-19 pandemic.

Johnson \& Johnson (2011) mention that parental support is an important element of education because parents can be relied on for assistance, support, and acceptance when students encounter difficulties or problems. Based on the previous studies, parental engagement is influenced by (1) beliefs that parents are strongly needed and related to the success of students' education (A'la \& Subhi, 2016); (2) perceptions of the available time at home (Hoover-Dempsey et al., 2005; Syaiful, 2020). Hence, it is important to know the role of parents in the counseling services since it is interactive and constructive processes between parents and experts indicated by collaborative efforts and common responsibilities and accountability.

Parents' position in learning and personality development of students has been the concern of researchers. Mutmainnah (2012) states that children personality potential is related to parenting style and environment. Parents must be present to give their best efforts for their children, such as finding the best school and love so that children can pass the developmental tasks, including having self-awareness and knowledge of their environment. Specifically, Lilawati (2020) in her study describes parental role in supporting children learning activities. Her study found several roles of parents during the implementation of SFH during this pandemic, such as learning motivators and facilitators for learning engagement. Even though previous two studies were done to early childhood population, the ideas can be used to consider the importance of parents in their children learning, including online counseling services.

A study by Umar (2015) found that parents are the main person in charge of children's education and future determiners. They hold a significant role to determine children educational success so that parents' role and responsibility take place in guiding the execution of specified programs. Certainly, parents must be able to guide their children to study at home, such as by providing monitoring, assistance of school work 
management, fulfilling children's learning instrument and infrastructure for online counseling services. Another study is from (Beck, et al., 2014; Kong, 2018) which identified parents' understanding, parental support, and the effectiveness of online counseling. This study aimed to determine, reveal and describe the role of parents in the implementation of supporting technology in online counseling during the COVID-19 pandemic. Regarding the previous elaboration, the hypothesis of this study is the level of parents' understanding in the technology utilization in guidance and counseling during the COVID-19 pandemic will influence the support for the online counseling services implementation.

\section{Literature Review the Role of Parents}

During the COVID-19 pandemic, parents must be present to accompany their children learning process at home, including during online counseling session. This form of engagement is realized as an effort to increase the effectiveness of counseling services. It is because, in the scope of school, parents are structured, collaborative and problemsolving partners between counselors (in this case is guidance and counseling teachers) and other parents who have consultations (Sheridan, et. al., 1996). This definition implies that the role of parents in the counseling is an interactive and constructive process along with some experts (Idol, et al., 1994) indicated by collaborative efforts as well as common responsibility and accountability (Reschly \& Christenson, 2012). To sum up, the previous studies found that parental engagement is influenced by 1) beliefs that parents are strongly needed and related to the success of students' education, and 2) perceptions of the available time at home (Hoover-Dempsey et al., 2005). In line with (Borutp, et. al, 2013), parental engagement in online learning process is necessary to help students do time management. This must be done because parents play a role as an important element to support school educational services (Diniaty, 2017).

\subsection{The Application of Services Technology During the COVID-19 Pandemic}

When the COVID-19 pandemic swept across the world in 2020, schools were closed and learning process was shifted to study from home. Facing this unexpected situation, many countries immediately changed their learning system to online learning (Starkey, et al., 2021). Thus, technology utilization becomes the efficient way to adopt as means of counseling services implementation (Haryati, 2020; Lin \& Wang, 2012). In this way, counseling services will be done virtually or online without any physical contact and face-to-face meeting between counselees (in this case is student) or parents with counselors (guidance and counseling teachers).

Online counseling through the utilization of technology provides a sense of security because counselees can join the services within their environment and even in a critical condition (Centore \& Milacci, 2008). It should be kept in mind that technologyintegrated counseling requires counselees to have assistants. Thus, parents' role in the implementation of technology in counseling services is significant to be studied. Of this 
technological implementation, school counselors can cope with students' stress, anxiety, and problems by using technology and social media, such as consultation videos (Greenhalgh et al., 2020). It is expected that the utilization of technological development in the scope of guidance and counseling can answer challenges and issues that occur during the pandemic.

\section{Method}

The present study used a survey method with cross-sectional technique given to students' parents all over Semarang Regency amounted to 350 people. Their data were collected online using Google Form.

Parental perception of learning designed by Kong (2018) was the instrument used to collect the data during the survey. It specifically examines parental perceptions of online learning carried out by students. Overall, this instrument consists of 17 items divided into 2 sub-scale, namely (a) parental perceptions of online counseling at the level of understanding, and (b) parental perceptions of online counseling at the level of support. Prior its distribution, the instrument has been through several adoption processes based on Lenz' concepts (2017), namely 1) forward translation, 2) translation review, decentralization and reconciliation of terms and constructs, 3) back-translation, 4) team review and further cultural adaptation, 5) pre-testing and revision, 6) qualitative evaluations, 7) team review and consensus forming, and 8) final assessment adapted to target language.

Respondents were asked to give score for the frequency of online counseling services received by their children based on their observation at home starting from 1 (never) until 5 (very often). The example of item to assess and identify parents' understanding is "I think online counseling services are important for my children future." Of 14 items, there found only 3 items invalid, so all items were used in this study. The items gained the level of reliability and validity of $(r=0.460-0.830)$, and Cronbach's alpha of 0.817. In addition, to analyze the data, the researchers used descriptive statistical analysis aiming at determining the role of parents in the implementation of supporting technology in the counseling services during the COVID-19 pandemic. The tool was linear regression analysis with the help of SPSS version 24 .

\section{Results and Discussion Descriptive Analysis}

Initially, the researchers performed an analysis using IBM SPSS version 24 on the data of 350 students' parents. The data can be seen in table 1, including gender, educational level from Junior High School (SMP), Senior High School (SMA), and Vocational High School (SMK). In details, the results of descriptive analysis of parental perception can be seen in table 2. This table presents mean, median, and standard deviation. 

SERVICES TECHNOLOGY DURING THE COVID-19 PANDEMIC

\begin{tabular}{l}
\hline \multicolumn{3}{|c|}{ Table 1: The Data of Study Sample } \\
\begin{tabular}{|l|c|c|}
\hline \multicolumn{1}{|c|}{ Frequency } & $\%$ \\
\hline Gender & & 59.7 \\
\hline Male & 141 & 40.3 \\
\hline Female & 209 & \\
\hline Educational Level & 125 & 35.7 \\
\hline SMP & 171 & 48.9 \\
\hline SMA & 54 & 15.4 \\
\hline SMK & & \\
\hline
\end{tabular}
\end{tabular}

Based on the above table, it is known that this study involved 350 respondents consisting of 141 or $59.7 \%$ female, and 209 or $40.3 \%$ female. In terms of educational level, it was dominated by parents whose students attended SMA as many as 171 respondents or $48.9 \%$, SMP as many as 125 respondents or $35.7 \%$, and SMK as many as 43 respondents or $15.4 \%$. It can be concluded that parents involved in this study had their children attended various the educational level.

Table 2: Descriptive Data

\begin{tabular}{|l|c|c|c|c|}
\hline Category & Understanding & & Support & \\
\hline Low & $\mathbf{N}$ & $\mathbf{\%}$ & $\mathbf{N}$ & $\mathbf{\%}$ \\
\hline Fair & 71 & 20.3 & 66 & 18.9 \\
\hline High & 189 & 54.0 & 196 & 56.0 \\
\hline Total & 90 & 25.7 & 88 & 25.1 \\
\hline M & 350 & 100 & 350 & 100 \\
\hline SD & 20.68 & & \multicolumn{2}{|c|}{3.05} \\
\hline
\end{tabular}

The results of parental perception of e-learning instrument showed that parents who had a high level of understanding category were as many as 90 people or $25 \%$, fair category of 189 people or $54 \%$, and low category of 71 people or $20.3 \%$. In other words, most of parents had fair category. Besides, it can be known that parents who had high level of support were as many as 88 people or $25 \%$, fair level as many as 196 people or $5.0 \%$, and low level as many as 66 people or $18.9 \%$. Thus, the majority of parents had fair level category of support.

Table 3: The Effect of Understanding on Support

\begin{tabular}{|c|c|c|c|c|c|c|c|c|}
\hline Criterium & Predictor & $\boldsymbol{\beta}$ & $\mathbf{t}$ & $\mathbf{p}$ & $\mathbf{R}$ & $\mathbf{R 2}$ & $\mathbf{F}$ & $\mathbf{P}$ \\
\hline Support & Understanding & 0.55 & 21.75 & 0.00 & 0.75 & 0.57 & 473.4 & 0.00 \\
\hline
\end{tabular}

In Table 3, the effect of understanding and support gained positive and significant results $(\beta=0.55 ; t=21.75 ; p<0.05)$. It indicated that if parents have a high level of understanding in online counseling services, the level of parental support will be higher. 


\section{Discussion}

The COVID-19 pandemic affected educational policies. One of policy applied during this pandemic is the implementation of distant learning (Bestiantono et al., 2020). Various media are used to support the learning process, for example, Google Classroom, Zoom, educational TV, ruang guru and other online learning applications (Nilam et al., 2020). Counselors as counseling service professionals need to do adaptation to face significant challenges in the implementation of online counseling (König et al., 2020).

Online counseling services implementation can run well with the support of parents. This kind of counseling urges to be done since the COVID-19 pandemic has affected all elements of life, especially economy, health, and education (Bostan et al., 2020) although parents may find it difficult in providing learning facilities for their children (Kong, 2018). Issues like this motivated the researchers to identify the extent to which parental understanding about online counseling contributes to the provision of support for online counseling services.

With regard to the findings, there was a positive effect of parents' understanding on the support for online counseling services. This is supported by the findings of Kong's study (2018) that parents who have good understanding about online counseling services will provide support and facilities. Accordingly, counselors' ability to give positive information to parents will positively influence their understanding and support (Tsuei $\& \mathrm{Hsu}, 2019)$. It proves that collaborative competence becomes the main factor in implementing online counseling services. Further, by having counselors socialize the benefits of online counseling services in children's learning, it is expected that the level of parental support will get higher and in turn provide facilities for the implementation of online counseling.

The fair level of parents' understanding found in this study influenced their support for online counseling services. It is in accordance with a study by (Mutambara \& Bayaga, 2020) that when parents have positive feelings towards online counseling services, these feelings will strengthen their intention to allow their children to carry out online counseling services for self-development. Hwang \& Hariyanti (2020) found that parents believe that the use of mobile devices is beneficial for learning, but they are worried about excessive use at the same time. This means that even though parents have knowledge about the benefits of online counseling services for self-development, concerns about increasing internet quota cost affect their attitudes towards online counseling services.

\section{Limitations}

There are several limitations to the findings of this study that can be concern for future studies. First, the samples of this study did not represent national scale level because it was only taken from parents whose children studied at Junior High School and Senior or Vocational High School around Semarang Regency. It also implies that this study did not 
specify the analysis on a particular educational level. Second, the researchers got difficulties in collecting respondents' data in which its process took 2 months to complete. Sometimes, the information given was seemingly accurate and represented the real conditions due to different thoughts and understanding of each respondent. Another factor, namely the online medium used to collect the data also became a shortcoming because this study could not cover all levels of society so that the collected data were as many as 350 respondents. This number was far from the target that has been determined previously in this study.

\section{Conclusions and Recommendations}

This study was designed to determine the role of parents in the implementation of guidance and counseling services technology during the COVID-19 pandemic in Semarang Regency. Generally, the findings derived from linear regression analysis indicate that students' parents have good understanding of the online counseling services, so their support becomes increasingly great too.

It is suggested that guidance and counseling teachers should improve the quality of online counseling services during this COVID-19 pandemic and collaborate with students' parents to achieve the common goals of the online counseling implementation. Then, the teachers are also recommended to search for or identify weaknesses in the online counseling services for better implementation in the future. Additionally, the future studies are expected to refer to the findings of this study in conducting investigations and development of renewable and user-friendly online counseling services media for students and parents as well as examining the effectiveness of online counseling services given to students during the COVID-19 pandemic.

\section{Conflict of Interest Statement}

The authors declare that they have no competing interests.

\section{About the Authors}

Awalya Awalya is a full-time lecturer in the Counseling Guidance Study Program, Semarang State University, Indonesia. His research interests include Guidance and Counseling, Guidance and Counseling Management, e-counseling. His research interests are centered on Guidance and Counseling Management in school settings.

Yudhi Purwa Nugraha is a full time lecturer in the Counseling Guidance Study Program at the Islamic University Of Jember, Indonesia. Research interests in counseling, online counselling, counselor competence, game addiction, career planning and positive psychology.

Endang Rifani is a full time lecturer in the Counseling Guidance Study Program at the University of Nahdlatul Ulama Al-Ghazali, Cilacap, Indonesia. Research interest in counselling, online counselling, morality, counselor competence, and mental health. 
Angga Yuda Meilanda, recent graduate with a degree in Guidance and Counseling at State University of Semarang, Jawa Tengah, Indonesia. Research interest in Counseling, career counseling, career development, online counseling, multicultural counseling, and mental health.

Rudianto Jati Widigdo, is a student of post graduate Guidance and Counselling at Semarang State University, Semarang, Central Java, Indonesia. Research interest in Counselling, online counselling, and mental health.

\section{References}

A'la, R., \& Subhi, M. R. (2016). Perhatian Orang Tua dan Motivasi Belajar Siswa. Madaniyah, $6(2)$,

242-259. https://journal.stitpemalang.ac.id/index.php/madaniyah/article/view/96/79

Beck, D. E., Maranto, R., \& Lo, W.-J. (2014). Determinants of student and parent satisfaction at a cyber charter school. The Journal of Educational Research, 107(3), 209-216. https://doi.org/10.1080/00220671.2013.807494

Bestiantono, D. S., Agustina, P. Z. R., \& Cheng, T.-H. (2020). How Students' Perspectives about Online Learning Amid the COVID-19 Pandemic? Studies in Learning and Teaching, 1(3), 133-139. https://doi.org/10.46627/silet.v1i3.46

Borup, J., Graham, C. R., \& Davies, R. S. (2013). The nature of parental interactions in an online charter school. American Journal of Distance Education, 27(1), 40-55. https://doi.org/10.1080/08923647.2013.754271

Bostan, S., Erdem, R., Öztürk, Y. E., Kılıç, T., \& Yılmaz, A. (2020). The effect of COVID-19 pandemic on the Turkish society. Electronic Journal of General Medicine, 17(6). https://doi.org/10.29333/ejgm/7944

Centore, A. J., \& Milacci, F. (2008). A Study of Mental Health Counselors' Use of and Perspectives on Distance Counseling. Journal of Mental Health Counseling, 30(3). https://doi.org/10.17744/mehc.30.3.q871r684n863u75r

Diniaty, A. (2017). Dukungan Orangtua terhadap Minat Belajar Siswa. Jurnal Al- Taujih, 3(1), 90-100. https://journal.stitpemalang.ac.id/index.php/madaniyah

Greenhalgh, T., Wherton, J., Shaw, S., \& Morrison, C. (2020). Video consultations for covid19. British Medical Journal Publishing Group. 10.1136/bmj.m998

Gunawan, Suranti, N. M. Y., \& Fathoroni. (2020). Variations of Models and Learning Platforms for Prospective Teachers During the COVID-19 Pandemic Period.

Indonesian Journal of Teacher Education, 1(2), 61-70. https://journal.publicationcenter.com/index.php/ijte/article/view/95

Haryati, A. (2020). Online Counseling Sebagai Alternatif Strategi Konselor dalam Melaksanakan Pelayanan E-Counseling di Era Industri 4.0. Bulletin of Counseling and Psychotherapy, 2(2), 27-38. https://doi.org/10.51214/bocp.v2i2.33

Hoover-Dempsey, K. V, Walker, J. M. T., Sandler, H. M., Whetsel, D., Green, C. L., Wilkins, A. S., \& Closson, K. (2005). Why do parents become involved? 
Research findings and implications. The Elementary School Journal, 106(2), 105- 130. https://doi.org/10.1086/499194

Hwang, W. Y., \& Hariyanti, U. (2020). Investigation of students' and parents' perceptions of authentic contextual learning at home and their mutual influence on technological and pedagogical aspects of learning under covid-19. Sustainability (Switzerland), 12(23), 1-19. https://doi.org/10.3390/su122310074

Idol, L., Nevin, A., \& Paolucci-Whitcomb, P. (1994). Collaborative consultation. Pro- ed. https://psycnet.apa.org/record/1994-97903-000

Johnson, D. W., \& Johnson, R. T. (2011). Cooperative learning. The Encyclopedia of Peace Psychology.

Kong, S. C. (2018). Parents' perceptions of e-learning in school education: implications for the partnership between schools and parents. Technology, Pedagogy and Education, 27(1), 15-31. https://doi.org/10.1080/1475939X.2017.1317659

König, J., Jäger-Biela, D. J., \& Glutsch, N. (2020). Adapting to online teaching during COVID-19 school closure: teacher education and teacher competence effects among early career teachers in Germany. European Journal of Teacher Education, 43(4), 608-622. https://doi.org/10.1080/02619768.2020.1809650

Lenz, A. S., Soler, I. G., Dell'Aquilla, J., \& Uribe, P. M. (2017). Translation and crosscultural adaptation of assessments for use in counseling research. Measurement and Evaluation in Counseling and Development, 50(4), 224-231. https://doi.org/10.1080/07481756.2017.1320947

Lilawati, A. (2020). Peran orang tua dalam mendukung kegiatan pembelajaran di rumah pada masa pandemi. Jurnal Obsesi: Jurnal Pendidikan Anak Usia Dini, 5(1), 549-558. https://doi.org/10.31004/obsesi.v5i1.592

Lin, W. S., \& Wang, C. H. (2012). Antecedences to continued intentions of adopting elearning system in blended learning instruction: A contingency framework based on models of information system success and task-technology fit. Computers and Education, 58(1), 88-99. https://doi.org/10.1016/j.compedu.2011.07.008

Mutambara, D., \& Bayaga, A. (2020). Understanding rural parents' behavioral intention to allow their children to use mobile learning. Conference on E-Business, e-Services and e-Society, 520-531. https://doi.org/10.1007/978-3-030-44999-5 43

Muthmainnah. (2012). Peran orang tua dalam menumbuhkan pribadi anak yang androgynius melalui kegiatan bermain. Jurnal Pendidikan Anak, 1(1). https://journal.uny.ac.id/index.php/jpa/article/download/2920/2424

Nilam, D., Sari, W., \& Mulu, M. (2020). Explorative study on the application of learning model in virtual classroom during Covid-19 pandemic at the school of Yogyakarta Province. Proceeding Umsurabaya, 0(0), 54. http://journal.umsurabaya.ac.id/index.php/Pro/article/view/5951

Reschly, A. L., \& Christenson, S. L. (2012). Moving from "context matters" to engaged partnerships with families. Journal of Educational and Psychological Consultation, 22(1-2), 62-78. https://doi.org/10.1080/10474412.2011.649650 
Sheridan, S. M., Kratochwill, T. R., \& Bergan, J. R. (1996). Conjoint behavioral consultation: A procedural manual. Springer Science \& Business Media. https://www.springer.com/gp/book/9781475725124

Starkey, L., Shonfeld, M., Prestridge, S., \& Cervera, M. G. (2021). Covid-19 and the role of technology and pedagogy on school education during a pandemic. Taylor \& Francis. https://doi.org/10.1080/1475939X.2021.1866838

Syaiful, S. (2020). Preferensi orang tua dalam memilih pondok pesantren sebagai tempat pendidikan bagi anak. Jurnal Konseling Pendidikan Islam, 1(2), 118-128. https://doi.org/10.32806/jkpi.v1i2.27

Tsuei, M., \& Hsu, Y. Y. (2019). Parents' acceptance of participation in the integration of technology into children's instruction. Asia-Pacific Education Researcher, 28(5), 457467. https://doi.org/10.1007/s40299-019-00447-3

Umar, M. (2015). Peranan orang tua dalam peningkatan prestasi belajar anak. JURNAL EDUKASI: Jurnal Bimbingan Konseling, 1(1), 20-28. http://dx.doi.org/10.22373/je.v1i1.315 
Author(s) will retain the copyright of their published articles agreeing that a Creative Commons Attribution 4.0 International License (CC BY 4.0) terms will be applied to their work. Under the terms of this license, no permission is required from the author(s) or publisher for members of the community to copy, distribute, transmit or adapt the article content, providing a proper, prominent and unambiguous attribution to the authors in a manner that makes clear that the materials are being reused under permission of a Creative Commons License. Views, opinions and conclusions expressed in this research article are views, opinions and conclusions of the author(s). Open Access Publishing Group and European Journal of Education Studies shall not be responsible or answerable for any loss, damage or liability caused in relation to/arising out of conflicts of interest, copyright violations and inappropriate or inaccurate use of any kind content related or integrated into the research work. All the published works are meeting the Open Access Publishing requirements and can be freely accessed, shared, modified, distributed and used in educational, commercial and non-commercial purposes under a Creative Commons Attribution 4.0 International License (CC BY 4.0). 